\title{
Anti-inflammatory and anti-coagulatory activities of caffeic acid and ellagic acid in cardiac tissue of diabetic mice Pei-chun Chao ${ }^{1,2}$, Cheng-chin $\mathrm{Hsu}^{1}$ and Mei-chin Yin*3
}

\author{
Address: ${ }^{1}$ Department of Nutritional Science, Chung Shan Medical University, Taichung City, Taiwan, Republic of China, ${ }^{2}$ Department of \\ Nutrition, Chung Shan Medical University Hospital, Taichung City, Taiwan, Republic of China and ${ }^{3}$ Department of Nutrition, China Medical \\ University, Taichung City, Taiwan, Republic of China \\ Email: Pei-chun Chao - cshc029@csh.org.tw; Cheng-chin Hsu - king@camu.edu.tw; Mei-chin Yin* - mcyin@mail.cmu.edu.tw \\ * Corresponding author
}

Published: 14 August 2009

Nutrition \& Metabolism 2009, 6:33 doi:10.1 186/1743-7075-6-33
Received: 24 June 2009

Accepted: 14 August 2009

This article is available from: http://www.nutritionandmetabolism.com/content/6/1/33

(C) 2009 Chao et al; licensee BioMed Central Ltd.

This is an Open Access article distributed under the terms of the Creative Commons Attribution License (http://creativecommons.org/licenses/by/2.0), which permits unrestricted use, distribution, and reproduction in any medium, provided the original work is properly cited.

\begin{abstract}
Background: Caffeic acid (CA) and ellagic acid (EA) are phenolic acids naturally occurring in many plant foods. Cardiac protective effects of these compounds against dyslipidemia, hypercoagulability, oxidative stress and inflammation in diabetic mice were examined.
\end{abstract}

Methods: Diabetic mice were divided into three groups (I5 mice per group): diabetic mice with normal diet, $2 \%$ CA treatment, or $2 \%$ EA treatment. One group of non-diabetic mice with normal diet was used for comparison. After 12 weeks supplement, mice were sacrificed, and the variation of biomarkers for hypercoagulability, oxidative stress and inflammation in cardiac tissue of diabetic mice were measured.

Results: The intake of CA or EA significantly increased cardiac content of these compounds, alleviated body weight loss, elevated plasma insulin and decreased plasma glucose levels in diabetic mice $(p<0.05)$. These treatments also significantly enhanced plasma antithrombin-III and protein $C$ activities $(p<0.05)$; and decreased triglyceride content in cardiac tissue and plasma $(p<0.05)$, in which the hypolipidemic effects of EA were significantly greater than that of CA $(p<0.05)$. CA or EA significantly lowered cardiac levels of malondialdehyde, reactive oxygen species, interleukin (IL)-beta, IL-6, tumor necrosis factor (TNF)-alpha and monocyte chemoattractant protein (MCP)I $(p<0.05)$; and retained cardiac activity of glutathione peroxidase (GPX), superoxide dismutase (SOD) and catalase $(p<0.05)$. These compounds also significantly up-regulated cardiac mRNA expression of GPXI, SOD and catalase; and down-regulated IL-I beta, IL-6, TNF-alpha and MCP-I mRNA expression in diabetic mice $(p<0.05)$.

Conclusion: These results support that CA and EA could provide triglyceride-lowering, anticoagulatory, anti-oxidative, and anti-inflammatory protection in cardiac tissue of diabetic mice. Thus, the supplement of these agents might be helpful for the prevention or attenuation of diabetic cardiomyopathy.

\section{Background}

Diabetic cardiomyopathy, one of diabetic complications, remains the major cause of mortality in people with dia- betes [1]. Lipid disorder, coagulation predomination, oxidative stress and inflammatory injury are important factors responsible for the development of diabetic cardi- 
omyopathy because these factors promote the progression of premature atherosclerosis, coronary insufficiency and myocardial infarction [2]. The hypercoagulability occurred in diabetic patients is due to the upregulation of blood coagulation factors such as fibrinogen, and/or downregulation of anticoagulation factors such as antithrombin-III (AT-III) [2,3]. Diabetes associated oxidative stress resulted from hyperglycemia-induced overproduction of free radicals and reactive oxygen species (ROS) could cause necrosis and/or apoptosis in cardiomyocytes $[4,5]$. In addition, disturbed balance between Th1 and Th2 cytokines and overproduced pro-inflammatory cytokines such as interleukin (IL)-1beta, tumor necrosis factor (TNF)-alpha and monocyte chemoattractant protein-1 (MCP-1) enhance systemic inflammatory stress and exacerbate diabetes associated cardiac dysfunctions [6,7]. Thus, any agent(s) with lipid-lowering, anti-coagulatory, anti-oxidative and/or anti-inflammatory activities may potentially prevent or delay the occurrence of diabetic cardiomyopathy.

Caffeic acid and ellagic acid are phenolic acids naturally occurring in many plant foods such as carrot, tomato, strawberry and blueberry [8,9]. It has been documented that these phenolic acids possess anti-oxidative activities such as scavenging free radicals and chelating metal ions $[10,11]$. Yamada et al. [12] reported that oral administration of caffeic acid resulted in the presence of its intact form in mice liver. However, the information regarding the accumulation of caffeic acid or ellagic acid in cardiac tissue after dietary supplement is lacked. On the other hand, the anti-diabetic effects of caffeic acid have been examined $[13,14]$; and these authors observed that this compound could decrease blood glucose level. So far, less information is available regarding the anti-diabetic effect of ellagic acid; and it also remains unknown that caffeic acid or ellagic acid could protect cardiac tissue against diabetes associated dyslipidemia, hypercoagulability, oxidative stress and inflammation.

The major purpose of this study was to investigate the lipid-lowering, anti-coagulatory, anti-oxidative and antiinflammatory effects of caffeic acid and ellagic acid in cardiac tissue of diabetic mice. Also, the impact of these compounds on cardiac mRNA expression of antioxidant enzymes and cytokines was examined. These results could elucidate the possible action modes from these compounds against diabetic cardiomyopathy.

\section{Materials and methods Materials}

Caffeic acid (CA, 99\%), ellagic acid (EA, 99.5\%) and other chemicals were purchased from Sigma Chemical Co. (St. Louis, MO, USA). All chemicals used in measurements were of the highest purity commercially available.

\section{Animals}

Male Balb/c mice, 3-4 wk old, were obtained from National Laboratory Animal Center (National Science Council, Taipei City, Taiwan). Mice were housed on a 12$\mathrm{h}$ light:dark schedule; water and mouse standard diet were consumed ad libitum. The use of mice was reviewed and approved by China Medical University animal care committee (CMU-97-22-N). To induce diabetes, mice with body weights of $22.9 \pm 0.8 \mathrm{~g}$ were treated with a single i.v. dose $(50 \mathrm{mg} / \mathrm{kg})$ of streptozotocin dissolved in citrate buffer ( $\mathrm{pH} 4.5$ ) into the tail vein of 12-h fasted mice. The blood glucose level was monitored on d 5 and 10 from the tail vein using a one-touch blood glucose meter (Lifescan, Inc. Milpitas, CA, USA). Mice with fasting blood glucose levels $\geq 14.0 \mathrm{mmol} / \mathrm{l}$ were used for this study.

\section{Experimental design}

CA or EA at $2 \mathrm{~g}$ was mixed with $98 \mathrm{~g}$ power diet containing (g/100 g): 64 starch, 23 protein, 3.5 fat, 5 fiber, 1 vitamin mixture and 3 salt mixture (PMI Nutrition International LLC, Brentwood, MO, USA). After diabetes was induced, mice were divided into three groups (15 mice per group): diabetic mice with normal diet, diabetic mice with $2 \% \mathrm{CA}$ treatment, and diabetic mice with $2 \%$ EA treatment. One group of non-diabetic mice with normal diet was used for comparison. All mice had free access to food and water at all times. Body weight, consumed water volume and food were recorded. After 12 wk supplementation, mice were sacrificed with carbon dioxide. Blood was collected, and plasma was separated from erythrocytes immediately. Cardiac tissue was removed and perfused for $2 \mathrm{~min}$ by phosphate buffer saline (PBS, $\mathrm{pH} 7.2$ ) to remove the remaining blood. Cardiac tissue at $0.2 \mathrm{~g}$ was homogenized on ice in $2 \mathrm{ml}$ PBS, and the filtrate was collected. The protein concentration of plasma or cardiac tissue filtrate was determined by the method of Lowry et al. [15] using bovine serum albumin as a standard. In all experiments, the sample was diluted to a final concentration of $1 \mathrm{~g}$ protein/l using PBS, pH 7.2.

\section{Content of CA or EA in cardiac tissue}

An HPLC method described in Yamada et al. [12] was used to analyze the cardiac content of intact form of CA or EA, in which an octadecylsilica column $(4.6 \times 250 \mathrm{~mm}$, Wakopak, Wako Pure Chemical Industry, Tokyo, Japan), and a mobile phase consisting of $95.6 \% \mathrm{H}_{2} \mathrm{O}, 4.1 \%$ ethyl acetate and $0.3 \%$ acetic acid were used at $30^{\circ} \mathrm{C}$ with a flow rate of $0.8 \mathrm{ml} / \mathrm{min}$.

\section{Assay of glucose, insulin, alanine aminotransferase (ALT) and aspartate aminotransferase (AST) activities}

Plasma glucose level ( $\mathrm{mmol} / \mathrm{l})$ was measured by a glucose kit (Sigma Chemical Co., St. Louis, MO, USA). Plasma insulin level (nmol/l) was measured by using a rat insulin radioimmunoassay kit (SRI-13K, Linco Research Inc., St. 
Charles, MO, USA). For glucose and insulin, the intra coefficients of variation (CVs) were 7.1 and $5.4 \%$; and the inter CVs were 6.3 and $5.8 \%$. Serum activity of ALT and AST were determined by using commercial assay kits (Randox Laboratories Ltd., Crumlin, UK), their intra and inter CVs were in the range of $2.5-4.6 \%$.

\section{Lipid analyses}

Triglyceride (TG) and total cholesterol (TC) levels (g/l) in plasma were determined by triglycerides/GB kit and cholesterol/HP kit (Boehringer Mannheim, Germany), respectively. For TG and TC, their intra CVs were 4.3 and 5.0\%; and their inter CVs were 3.7 and $4.8 \%$. Total lipids were extracted from cardiac tissue, TG concentration (mg/ $\mathrm{g}$ wet tissue) was quantified by a colorimetric assay [16], and total cholesterol (mg/g wet tissue) was measured using $o$-phthalaldehyde [17].

\section{Measurement of blood coagulation and anticoagulation factors}

Blood samples were anticoagulated using sodium citrate according to the protocols provided by the manufacturers of the kits used. Plasma fibrinogen level (g/l) was measured based on the principle of salting out using a commercial kit (Iatroset Fbg, Iatron Laboratory, Tokyo, Japan). Plasminogen activator inhibitor-1 (PAI-1) activity (kU/l) was assayed by a commercial kit (Trinity Biotech plc, Co. Wicklow, Ireland). For fibrinogen and PAI-1, the intra and inter CVs ranged from 5.4 to $6.7 \%$. The activity (\%) of ATIII and protein $\mathrm{C}$ in plasma was determined by chromogenic assays according to the manufacturer'sinstruction $\mathrm{s}$ using commercial AT-III and protein C kits (Sigma Chemical Co., St. Louis, MO, USA), and was shown as ratio of those in normal human plasma. For AT-III and protein C, the intra CVs were 3.4 and $4.7 \%$; and the inter CVs were 6.0 and $7.2 \%$.

\section{Determination of oxidative and anti-oxidative status}

Glutathione (GSH) and oxidized glutathione (GSSG) concentrations (nmol/mg protein) in cardiac tissue were determined by commercial colorimetric GSH and GSSG assay kits (OxisResearch, Portland, OR, USA). For GSH and GSSG, the intra CVs were 5.0 and 5.8\%; and the inter CVs were 4.2 and $6.0 \%$. Glutathione peroxidase (GPX), catalase and superoxide dismutase (SOD) activities (U/ $\mathrm{mg}$ protein) in cardiac tissue were determined by commercial assay kits (Calbiochem Inc., San Diego, CA, USA). Their intra CVs were in the range of 6.3-7.5\%; and inter CVs were in the range of 5.9-7.8\%. Lipid oxidation in cardiac tissue was determined by measuring the level of malondialdehyde (MDA, $\mu \mathrm{mol} / \mathrm{mg}$ protein) via an HPLC method [18]. The method described in Privratsky et al. [19] was used to determine the amount of ROS in cardiac tissue. Briefly, $10 \mathrm{mg}$ cardiac tissue was homogenized in 1 $\mathrm{ml}$ of ice cold $40 \mathrm{mM}$ Tris-HCl buffer ( $\mathrm{pH} 7.4$ ), and fur- ther diluted to $0.25 \%$ with the same buffer. Then, samples were loaded with $10 \mu \mathrm{mol} / \mathrm{l} \mathrm{2',} \mathrm{7'-dichlorofluorescin} \mathrm{at}$ $37^{\circ} \mathrm{C}$ for $30 \mathrm{~min}$. After rinsing, and the fluorescence intensity was measured using a fluorescent microplate reader with excitation wavelength at $480 \mathrm{~nm}$ and emission wavelength at $530 \mathrm{~nm}$. Untreated samples were used to determine background fluorescence.

\section{Cardiac inflammatory factors analyses}

Cardiac tissue was homogenized in $10 \mathrm{mM}$ Tris-HCl buffered solution ( $\mathrm{pH} 7.4$ ) containing

$2 \mathrm{M} \mathrm{NaCl}, 1 \mathrm{mM}$ ethylenediaminetetraacetic acid, 0.01\% Tween 80, $1 \mathrm{mM}$ phenylmethylsulfonyl fluoride, and centrifuged at $9000 \times \mathrm{g}$ for $30 \mathrm{~min}$ at $4^{\circ} \mathrm{C}$. The resultant supernatant was used for cytokine determination. The levels of IL-1beta, IL-6, TNF-alpha, IL-4, IL-10 and MCP-1 were measured by ELISA using cytoscreen immunoassay kits (BioSource International, Camarillo, CA, USA). Samples were assayed in duplicates according to manufacturer's instructions. The sensitivity of the assay, i.e., the lower limit of detection, was $5 \mathrm{nmol} / \mathrm{l}$ for IL-1beta, IL-4, IL-6, IL-10 and $10 \mathrm{nmol} / \mathrm{l}$ for TNF-alpha and MCP-1.

\section{Real-time polymerase chain reaction (RT-PCR) for $m R N A$ expression}

RT-PCR was used to examine the cardiac mRNA expression of catalase, GPX1, SOD, IL-1beta, IL-6, TNF-alpha and MCP-1. Cardiac tissue was homogenized in guanidinethiocyanate, and RNA was extracted using TRIizol reagent and further digested with DNase. Two $\mu \mathrm{g}$ of total RNA was used to generate cDNA. Reverse transcription was performed in a one-step protocol using the iScript cDNA Synthesis Kit (Bio-Rad Co., Hercules, CA, USA) according to the manufacturer's instructions. The primers were as follows. Catalase: forward, 5'-TTC AGA AGA AAG CGG TCA AGA AT-3', reverse, 5'-GAT GCG GGC CCC ATA GTC-3'; GPX1: forward, 5'-CCC CAC TGC GCT CATGA-3', reverse, 5'-GGC ACA CCG GAG ACC AAA-3'; Cu-Zn SOD: forward, 5'-TGG GTT CCA CGT CCA TCA GTA-3', reverse, 5'-ACC GTC CTT TCC AGC AGT CA-3'; IL-1beta: forward,5'-TGT GGC TGT GGA GAA GCT GT-3', reverse, 5'-CAG CTC ATA TGG GTC CGA GA-3'; IL-6: forward, 5'CAC GGC CTT CCC TAC TTC AC-3', reverse, TGC AAG TGC ATC ATC GTT GT-3'; TNF-alpha: forward, 5'-ACT CAA CAA ACT GCC CTT CTG AG-3', reverse, 5'-TTA CAG CTG GTT TCG ATC CAT TT-3'; MCP-1: forward, 5'-CAG GTC CCT GTC ATG CTT CT-3', reverse, 5'-CAC TGT CAC ACT GGT CAC T-3'; glyceraldehyde-3-phosphate dehydrogenase (GAPDH): forward, 5'-TGA TGA CAT CAA GAA GGT GGT GAA G-3', reverse, 5'-CCT TGG AGG CCATGT AGG CCA T-3'. The target concentration was expressed relative to the concentration of a reference housekeeping gene, GAPDH. PCR was conducted using the following parameters: $50^{\circ} \mathrm{C}$ for $2 \mathrm{~min}, 95^{\circ} \mathrm{C}$ for $10 \mathrm{~min}$ and 40 

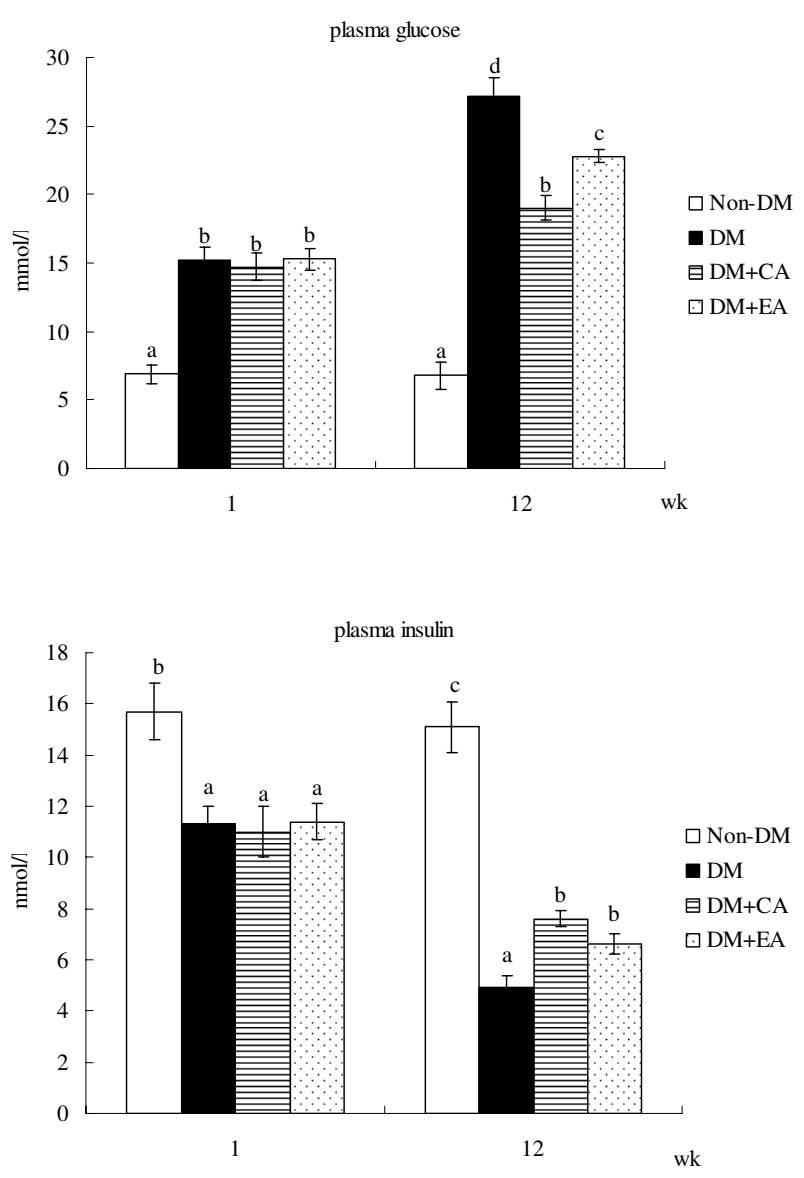

Figure I

Plasma level of glucose $(\mathrm{mmol} / \mathrm{l})$ or insulin $(\mathrm{nmol} / \mathrm{l})$ of non-diabetic mice (Non-DM), diabetic mice consumed normal diet (DM), $2 \%$ caffeic acid (CA) or ellagic acid (EA) at I and I 2 week. Data are mean $\pm S D$, $\mathrm{n}=15$. ${ }^{\mathrm{a}-\mathrm{d} M e a n s}$ among bars without a common letter differ, $p<0.05$.

cycles at $94^{\circ} \mathrm{C}$ for $20 \mathrm{~s}$ and $60^{\circ} \mathrm{C}$ for $1 \mathrm{~min}$. Generated fluorescence from each cycle was quantitatively analyzed by using the Taqman system based on real-time sequence detection system (ABI Prism 7700; Perkin-Elmer Inc., Foster City, CA, USA). In this present study, the mRNA level of the control group (without diabetes and with normal diet) was defined as 100\%; then, mRNA level of other groups were calculated as percentage of the control group.

\section{Statistical analysis}

All data were expressed as mean \pm standard deviation (SD). A statistical software package, SAS program (Version 5.1), was used to perform statistical analysis. One-way analysis of variance (ANOVA), followed by Dunnett's ttest was used to assess the significance of any change
Table I: Content of caffeic acid (CA) and ellagic acid (EA) in cardiac tissue from diabetic mice consumed normal diet (DM), $2 \%$ CA or EA at 12 week.

\begin{tabular}{llll}
\hline \multicolumn{4}{c}{$\begin{array}{l}\text { Cardiac tissue } \\
(\mathrm{mg} / \mathrm{l00} \mathrm{g} \text { wet tissue })\end{array}$} \\
& DM & DM+CA & DM+EA \\
\hline Caffeic acid & -a & $24.7 \pm 2.3$ & - \\
Ellagic acid & - & - & $29.5 \pm 3.5$ \\
\hline
\end{tabular}

ameans too low to be detected.

Data are mean $\pm S D, n=15$.

between groups. Statistical significance is defined as $p<$ 0.05 .

\section{Results}

The content of CA or EA in cardiac tissue is shown in Table 1. Dietary supplement of these compounds significantly increased their content in cardiac tissue of diabetic mice. Water intake, food intake, body weight and serum levels of ALT and AST at wks 1 and 12 are presented in Table 2. Compared with diabetic mice with normal diet, mice with CA and EA supplement had significantly lower water intake, lower food intake and higher body weight at wk 12 $(p<0.05)$. CA or EA treatment did not affect serum activity of ALT and AST in diabetic mice ( $p>0.05)$. Plasma levels of glucose and insulin are presented in Figure 1. Compared with diabetic mice with normal diet, CA and EA treatments significantly decreased glucose level and increased insulin level at wk $12(p<0.05)$.

Table 2: Water intake (WI, $\mathrm{ml} / \mathrm{mouse} / \mathrm{d}$ ), food intake (FI, g/ mouse/d), body weight (BW, g/mouse), serum alanine aminotransferase activity (ALT, U/I), aspartate aminotransferase activity (AST, U/I) of non-diabetic mice (NonDM), diabetic mice consumed normal diet (DM), $2 \%$ caffeic acid (CA) or ellagic acid (EA) at I and I 2 week.

\begin{tabular}{cllll}
\hline & Non-DM & DM & DM+CA & DM+EA \\
\hline WI & & & \\
I & $2.5 \pm 0.4^{\mathrm{a}}$ & $3.6 \pm 0.7^{\mathrm{a}}$ & $3.1 \pm 0.4^{\mathrm{a}}$ & $3.2 \pm 0.5^{\mathrm{a}}$ \\
I2 & $3.0 \pm 0.5^{\mathrm{a}}$ & $7.9 \pm 1.2^{\mathrm{c}}$ & $5.6 \pm 0.8^{\mathrm{b}}$ & $6.0 \pm 0.7^{\mathrm{b}}$ \\
$\mathrm{FI}$ & & & & \\
I & $2.2 \pm 0.6^{\mathrm{a}}$ & $2.4 \pm 0.5^{\mathrm{a}}$ & $2.3 \pm 0.7^{\mathrm{a}}$ & $2.5 \pm 0.6^{\mathrm{a}}$ \\
I2 & $3.1 \pm 1.0^{\mathrm{a}}$ & $7.2 \pm 1.3^{\mathrm{c}}$ & $5.8 \pm 0.8^{\mathrm{b}}$ & $6.1 \pm 0.9^{\mathrm{b}}$ \\
BW & & & & \\
I & $22.9 \pm 1.2^{\mathrm{b}}$ & $20.6 \pm 1.0^{\mathrm{a}}$ & $21.0 \pm 1.3^{\mathrm{a}}$ & $21.2 \pm 0.8^{\mathrm{a}}$ \\
I2 & $29.7 \pm 2.0^{\mathrm{d}}$ & $11.5 \pm 1.4^{\mathrm{a}}$ & $16.2 \pm 1.0^{\mathrm{c}}$ & $14.7 \pm 0.9^{\mathrm{b}}$ \\
$\mathrm{ALT}$ & & & & \\
I & $52 \pm 5^{\mathrm{a}}$ & $54 \pm 7^{\mathrm{a}}$ & $50 \pm 3^{\mathrm{a}}$ & $55 \pm 4^{\mathrm{a}}$ \\
I2 & $51 \pm 6^{\mathrm{a}}$ & $50 \pm 5^{\mathrm{a}}$ & $52 \pm 7^{\mathrm{a}}$ & $53 \pm 5^{\mathrm{a}}$ \\
AST & & & & \\
I & $75 \pm 9^{\mathrm{a}}$ & $72 \pm 4^{\mathrm{a}}$ & $77 \pm 5^{\mathrm{a}}$ & $70 \pm 7^{\mathrm{a}}$ \\
I2 & $74 \pm 6^{\mathrm{a}}$ & $73 \pm 8^{\mathrm{a}}$ & $71 \pm 5^{\mathrm{a}}$ & $72 \pm 4^{\mathrm{a}}$
\end{tabular}

Data are mean $\pm S D, n=15$.

a-dMeans in a row without a common letter differ, $p<0.05$. 
Table 3: Level of triglyceride (TG) and total cholesterol (TC) in cardiac tissue and plasma from non-diabetic mice (Non-DM), diabetic mice consumed normal diet (DM), $2 \%$ caffeic acid (CA) or ellagic acid (EA) at 12 week.

\begin{tabular}{|c|c|c|c|c|}
\hline & Non-DM & DM & $\mathrm{DM}+\mathrm{CA}$ & $\mathrm{DM}+\mathrm{EA}$ \\
\hline \multicolumn{5}{|l|}{ Cardiac tissue } \\
\hline TG, mg/g wet tissue & $25.4 \pm 1.8^{a}$ & $41.7 \pm 2.3^{d}$ & $36.8 \pm 1.7 c$ & $32.4 \pm 2.0^{b}$ \\
\hline TC, mg/g wet tissue & $2.9 \pm 0.8^{a}$ & $4.2 \pm 0.8^{b}$ & $4.0 \pm 0.9^{b}$ & $3.9 \pm 0.7^{b}$ \\
\hline \multicolumn{5}{|l|}{ Plasma } \\
\hline TG, g/l & $2.24 \pm 0.18^{a}$ & $4.16 \pm 0.34^{d}$ & $3.51 \pm 0.15^{c}$ & $3.04 \pm 0.2 \mathrm{I}^{\mathrm{b}}$ \\
\hline TC, g/l & $1.34 \pm 0.23^{a}$ & $3.67 \pm 0.3 \mathrm{lb}$ & $3.56 \pm 0.26^{b}$ & $3.6 \mathrm{I} \pm 0.23^{b}$ \\
\hline
\end{tabular}

a-dMeans in a row without a common letter differ, $p<0.05$.

Data are mean $\pm S D, n=I 5$.

TG and TC content in cardiac tissue and plasma at wk 12 are shown in Table 3. CA and EA treatments significantly lowered cardiac and plasma TG content ( $\mathrm{p}<0.05)$, in which the effect of EA was greater than that of CA ( $\mathrm{p}<$ $0.05)$. Both CA and EA failed to affect TC content in cardiac tissue and plasma ( $p>0.05)$. Plasma levels of coagulation and anti-coagulation factors at wk 12 are shown in Table 4. CA and EA treatments significantly elevated AT-III and protein $\mathrm{C}$ activities ( $\mathrm{p}<0.05)$; but failed to affect PAI1 activity and fibrinogen level in diabetic mice $(\mathrm{p}>0.05)$.

As shown in Table 5, CA or EA treatment significantly decreased cardiac levels of MDA, ROS and GSSG in diabetic mice $(p<0.05)$; these supplements also significantly increased cardiac GSH level and retained activity of GPX, SOD and catalase $(p<0.05)$. Cardiac levels of cytokines are presented in Table 6. CA or EA supplement significantly reduced IL-1beta, IL-6, TNF-alpha and MCP- 1 levels $(p<0.05)$; but these compounds failed to affect cardiac IL-4 and IL-10 levels ( $p>0.05)$. The effects of CA or EA on mRNA expression of cardiac catalase, SOD, GPX1, IL1beta, IL-6, TNF-alpha and MCP-1 are shown in Figure 2. CA or EA treatment significantly up-regulated mRNA expression of catalase, SOD and GPX1; and down-regulated IL-1beta, IL-6, TNF-alpha and MCP-1 mRNA expression in cardiac tissue of diabetic mice $(p<0.05)$.

\section{Discussion}

Our present study revealed that the dietary supplement of caffeic acid and ellagic acid increased cardiac content of these compounds in their intact forms; and these treatments effectively elevated insulin secretion, improved glycemic control, decreased plasma and cardiac triglyceride levels, diminished cardiac oxidative and inflammatory stresses, and attenuated coagulation risk in diabetic mice. These findings support that these agents could protect cardiac tissue against the progression of diabetic cardiomyopathy via these triglyceride-lowering, anti-oxidative, anti-coagulatory and anti-inflammatory effects.

We found that these compounds substantially elevated insulin secretion, which might subsequently attenuate dyslipidemia in CA or EA treated diabetic mice via improving lipid metabolism. Thus, the observed lower triglyceride accumulation in cardiac tissue and plasma could be explained. Diabetes is a thrombosis-prone condition because hyperglycemia-induced ROS causes platelet dysfunction, and insulin deficiency reduces the release of thrombolytic enzymes such as tissue plasminogen activators [20]. Activated AT-III and protein C are important anticoagulants because AT-III inhibits the activity of a number of proteases in the coagulation cascade, and protein $\mathrm{C}$ inactivates coagulation factors such as factors $\mathrm{Va}$ and VIIIa [21]. The results of our present study indicated that caffeic acid or ellagic acid treatment markedly elevated AT-III and protein $\mathrm{C}$ activities, which might consequently enhance anticoagulatory activity and alleviate diabetes associated hypercoagulability. These findings support that these compounds could improve hemostatic disorder and reduce the risk of diabetes associated athero-

Table 4: Coagulatory factors, PAI-I activity and fibrinogen level; anti-coagulatory factors, AT-III and protein C in plasma from nondiabetic mice (Non-DM), diabetic mice consumed normal diet (DM), $2 \%$ caffeic acid (CA) or ellagic acid (EA) at I2 week.

\begin{tabular}{lllll}
\hline & Non-DM & DM & DM+CA & DM+EA \\
\hline PAI-I, kU/l & $7.4 \pm 0.7^{\mathrm{a}}$ & $19.2 \pm 1.3^{\mathrm{b}}$ & $18.7 \pm 1.4^{\mathrm{b}}$ & $18.5 \pm 1.0^{\mathrm{b}}$ \\
Fibrinogen, g/l & $2.41 \pm 0.19^{\mathrm{a}}$ & $4.91 \pm 0.27^{\mathrm{b}}$ & $4.65 \pm 0.30^{\mathrm{b}}$ & $4.70 \pm 0.21^{\mathrm{b}}$ \\
AT-III, \% & $138 \pm 12^{\mathrm{c}}$ & $70 \pm 4^{\mathrm{a}}$ & $98 \pm 5^{\mathrm{b}}$ & $104 \pm 7^{\mathrm{b}}$ \\
Protein C, \% & $96 \pm 6^{\mathrm{c}}$ & $58 \pm 5^{\mathrm{a}}$ & $75 \pm 7^{\mathrm{b}}$ & $80 \pm 6 \mathrm{~b}$
\end{tabular}

a-cMeans in a row without a common letter differ, $p<0.05$.

Data are mean $\pm S D, n=15$. 

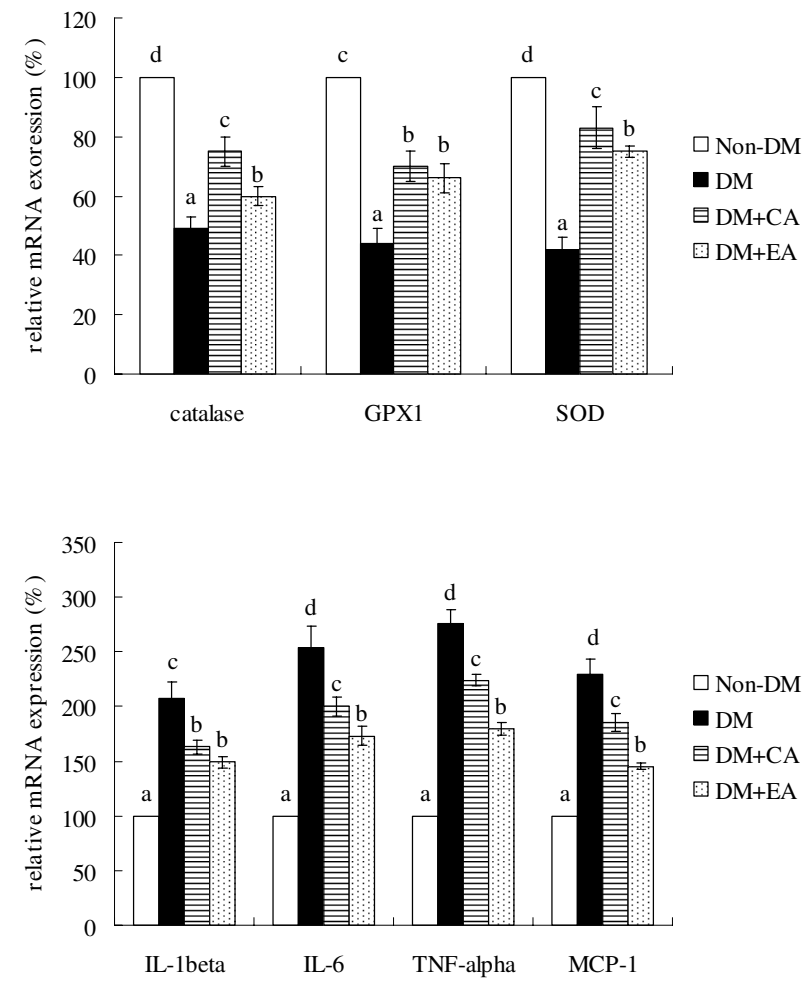

Figure 2

Cardiac mRNA expression of catalase, GPXI, SOD, IL-I beta, IL-6, TNF-alpha and MCP-I in mice without diabetes (Non-DM), diabetic mice consumed normal diet (DM), $2 \%$ caffeic acid (CA) or ellagic acid (EA) at 12 week. Data are mean $\pm S D, n=15$. a-d Means among bars without a common letter differ, $p<0.05$.

genesis and thrombosis via decreasing triglyceride level in circulation and cardiac tissue as well as enhancing activity of fibrinolytic factors such as AT-III and protein C. On the other hand, fibrinogen is a precursor in fibrin formation and a cofactor in platelet aggregation; PAI-1 is the primary physiologic inhibitor of fibrinolysis [22]. Our present study found that test compounds failed to affect fibrino- gen level and PAI-1 activity in diabetic mice. Obviously, these compounds could not attenuate hypercoagulability via suppressing coagulatory factors such as fibrinogen and PAI-1.

Diabetes is also an inflammation-prone condition because hyperglycemia-induced ROS stimulates signal transduction to elaborate inflammatory cytokines, e.g. TNF-alpha, IL-1beta and IL-6 [23], which facilitates inflammation, endothelial dysfunction, coagulation and exacerbated the severity of diabetes $[24,25]$. Our present study observed that caffeic acid or ellagic acid supplement effectively suppressed cardiac mRNA expression of these inflammatory cytokines, which contributed to diminish cardiac inflammatory reactions in diabetic mice. These results supported that these compounds were potent agents against diabetes-associated cardiac inflammation. We also notified that these compounds did not affect cardiac levels of IL-4 and IL-10, anti-inflammatory and immunosuppressive cytokines. Thus, the diminished diabetic cardiac inflammation from these agents was not due to their stimulation on the production of anti-inflammatory cytokines. It has been reported that elevated serum MCP-1 level could serve as an inflammatory marker in patients at risk for atherosclerotic vascular diseases because MCP-1 is a chemotactic factor for activating monocytes and macrophages, and could recruit monocytes to the sites of injury $[26,27]$. In our present study, the increased cardiac MCP-1 level indicated that these diabetic mice were at risk for cardio-vascular complications. Meanwhile, we also found that the supplement of caffeic acid and ellagic acid markedly lowered cardiac MCP-1 protein production in diabetic mice. These results indicated that these compounds could protect cardiac tissue against inflammation via decreasing the activation of monocytes and macrophages, and lowering the recruitment of monocytes.

It has been documented that caffeic acid and ellagic acid possess non-enzymatic antioxidant activity such as scavenging free radicals, and enzymatic antioxidant activity

Table 5: Level of MDA, ROS, GSSG, GSH and activity of catalase, GPX, SOD in cardiac tissue from non-diabetic mice (Non-DM), diabetic mice consumed normal diet (DM), $2 \%$ caffeic acid (CA) or ellagic acid (EA) at 12 week.

\begin{tabular}{|c|c|c|c|c|}
\hline & Non-DM & DM & $\mathrm{DM}+\mathrm{CA}$ & $\mathrm{DM}+\mathrm{EA}$ \\
\hline MDA, $\mu \mathrm{mol} / \mathrm{mg}$ protein & $0.63 \pm 0.09 a$ & $3.17 \pm 0.26^{d}$ & $1.45 \pm 0.13^{b}$ & $1.97 \pm 0.15^{c}$ \\
\hline ROS, nmol/mg protein & $0.31 \pm 0.09 a$ & $1.08 \pm 0.13^{c}$ & $0.83 \pm 0.07^{b}$ & $0.72 \pm 0.10^{b}$ \\
\hline GSSG, nmol/mg protein & $0.27 \pm 0.07^{\mathrm{a}}$ & $1.32 \pm 0.12^{\mathrm{d}}$ & $0.56 \pm 0.07^{b}$ & $0.83 \pm 0.05^{c}$ \\
\hline $\mathrm{GSH}, \mathrm{nmol} / \mathrm{mg}$ protein & $18.9 \pm 1.8^{d}$ & $10.6 \pm 1.0 \mathrm{a}$ & $14.6 \pm 1.2^{c}$ & $12.0 \pm 1.5^{b}$ \\
\hline GPX, U/mg protein & $35.4 \pm 2.6 c$ & $17.6 \pm 1.2^{\mathrm{a}}$ & $21.2 \pm 2.0^{b}$ & $22.6 \pm 2.3^{b}$ \\
\hline Catalase, U/mg protein & $27.3 \pm 2.0^{d}$ & $14.0 \pm 0.9 \mathrm{a}$ & $21.6 \pm 1.8^{c}$ & $18.7 \pm 1.5^{b}$ \\
\hline SOD, U/mg protein & $30.7 \pm 2.3^{d}$ & $16.9 \pm 1.0^{\mathrm{a}}$ & $23.1 \pm 1.6^{c}$ & $19.1 \pm 1.2^{b}$ \\
\hline
\end{tabular}

a-dMeans in a row without a common letter differ, $p<0.05$.

Data are mean $\pm S D, n=15$. 
Table 6: Cardiac level (pg/mg protein) of inflammatory cytokine (IL-I beta, IL-6, TNF-alpha and MCP-I), and anti-inflammatory cytokine (IL-4 and IL-I0) in non-diabetic (Non-DM), diabetic mice consumed normal diet (DM), $2 \%$ caffeic acid (CA) or ellagic acid (EA) at 12 week.

\begin{tabular}{lllll}
\hline & Non-DM & DM & DM+CA & DM+EA \\
\hline IL-Ibeta & $15 \pm 2^{\mathrm{a}}$ & $331 \pm 26^{\mathrm{c}}$ & $234 \pm 25^{\mathrm{b}}$ & $227 \pm 23^{\mathrm{b}}$ \\
IL-6 & $18 \pm 3^{\mathrm{a}}$ & $411 \pm 30^{\mathrm{d}}$ & $323 \pm 28^{\mathrm{c}}$ & $226 \pm 26^{\mathrm{b}}$ \\
TNF-alpha & $19 \pm 4^{\mathrm{a}}$ & $386 \pm 21^{\mathrm{d}}$ & $305 \pm 25^{\mathrm{c}}$ & $245 \pm 19^{\mathrm{b}}$ \\
MCP-I & $16 \pm 3^{\mathrm{a}}$ & $278 \pm 22^{\mathrm{d}}$ & $225 \pm 16^{\mathrm{c}}$ & $192 \pm 14^{\mathrm{b}}$ \\
& & & & \\
IL-4 & $14 \pm 4^{\mathrm{a}}$ & $230 \pm 24^{\mathrm{b}}$ & $227 \pm 21^{\mathrm{b}}$ & $219 \pm 26^{\mathrm{b}}$ \\
IL-10 & $17 \pm 3^{\mathrm{a}}$ & $209 \pm 30^{\mathrm{b}}$ & $198 \pm 19^{\mathrm{b}}$ & $204 \pm 29^{\mathrm{b}}$ \\
\hline
\end{tabular}

a-dMeans in a row without a common letter differ, $p<0.05$.

Data are mean $\pm S D, n=15$.

such as increasing protein level of antioxidant enzymes $[10,28]$. Our present study also observed that these compounds could alleviate cardiac oxidative stress via reducing the formation of MDA and ROS; and enhance antioxidant defense via increasing GSH retention and restoring the activity of three antioxidant enzymes as well as up-regulating cardiac mRNA expression of these antioxidant enzymes. Therefore, it is highly possible that the intake of these agents resulted in their accumulation in cardiac tissue, which subsequently decreased cardiac oxidative damage via their anti-oxidative activities. Then, both inflammatory and coagulatory stresses in cardiac tissue were alleviated because the available oxidants such as ROS as inflammation and/or coagulation stimulators were lowered.

Tasaki et al. [29] reported that dietary supplement of ellagic acid up to $5 \%$ was safe in rats. Ellagic acid or caffeic acid at $2 \%$ was sued in our present study, and we found these compounds at this dose exhibited marked cardiac protective effects and did not cause liver injury. Thus, these agents at this dose might be safe for diabetic application. Further study is necessary to verify the efficiency and safety of these compounds before they are used for human. It is interesting to find that caffeic acid was more effective in increasing GSH content and enhancing catalase and SOD activities; but ellagic acid was more effective in lowering IL-6, TNF-alpha and MCP-1 levels in cardiac tissue. Apparently, the cardiac protective action modes of these two compounds were not identical.

\section{Conclusion}

Dietary supplement of caffeic acid and ellagic acid improved glycemic control and lipid metabolism in diabetic mice. These compounds provided triglyceride-lowering, anti-coagulatory, anti-oxidative and antiinflammatory protection for cardiac tissue of diabetic mice. The impact of these agents on cardiac mRNA expression of antioxidant enzymes and cytokines revealed that their protective effects occurred at transcription level. Therefore, the supplement of these compounds might be helpful for the prevention or alleviation of diabetic cardiomyopathy.

\section{List of abbreviations used}

AT-III: antithrombin-III; GPX: glutathione peroxidase; GSH: glutathione; GSSG: oxidized glutathione; IL-1beta: interleukin-1beta; MCP-1: monocyte chemoattractant protein-1; MDA: malondialdehyde; PAI-1: plasminogen activator inhibitor-1; ROS: reactive oxygen species; RTPCR: real-time polymerase chain reaction; SOD: superoxide dismutase; TC: total cholesterol; TG: triglyceride; TNFalpha: tumor necrosis factor-alpha.

\section{Competing interests}

The authors declare that they have no competing interests.

\section{Authors' contributions}

All authors were involved in the design of this study; and performed laboratory analyses and statistics. The manuscript was written by Yin MC.

\section{References}

I. Tziakas DN, Chalikias GK, Kaski JC: Epidemiology of the diabetic heart. Coron Artery Dis 2005:S3-SI0.

2. Reasner CA: Reducing cardiovascular complications of type 2 diabetes by targeting multiple risk factors. J Cardiovasc Pharmacol 2008, 52:136-144.

3. Sowers JR, Epstein M, Frohlich ED: Diabetes, hypertension and cardiovascular disease: an update. Hypertension 200I, 37: 1053-1059.

4. Ye G, Metreveli NS, Donthi RV, Xia S, Xu M, Carlson EC, Epstein PN Catalase protect cardiomyocyte function in models of type $I$ and 2 diabetes. Diabetes 2004, 53:1336-1343.

5. Zhou G, Li X, Hein DW, Xiang X, Marshall JP, Prabhu SD, Cai L: Metallothionein suppresses angiotensin II-induced nicotinamide adenine dinucleotide phosphate oxidase activation, nitrosative stress, apoptosis, and pathological remodeling in the diabetic heart. J Am Coll Cardio 2008, 52:655-666.

6. Geerlings SE, Brouwer EC, van Kessel KC, Gaastra W, Stolk RP, Hoepelman AL: Cytokine secretion is impaired in women with diabetes mellitus. Euro J Clin Invest 2000, 30:995-100I.

7. Drimal J, Knezl V, Navarova J, Nedelcevova J, Paulovicova E, Sotnikova VR, Snirc V, Drimal D: Role of inflammatory cytokines and chemoattractants in rat model of streptozotocin-induced diabetic heart failure. Endo Regul 2008, 42:129-135.

8. Sellappan S, Akoh CC, Krewer G: Phenolic compounds and antioxidant capacity of Georgia-grown blueberries and blackberries. J Agric Food Chem 2002, 50:2432-2438.

9. Mattila P, Kumpulainen J: Determination of free and total phenolic acids in plant-derived foods by HPLC with diode-array detection. J Agric Food Chem 2002, 50:3660-3667.

10. Makena PS, Chung KT: Effects of various plant polyphenols on bladder carcinogen benzidine-induced mutagenicity. Food Chem Toxicol 2007, 45: 1899-1909.

II. Prakash D, Suri S, Upadhyay G, Singh BN: Total phenol, antioxidant and free radical scavenging activities of some medicinal plants. Int J Food Sci Nutr 2007, 58: I 8-28.

12. Yamada Y, Yasui H, Sakurai H: Suppressive effect of caffeic acid and its derivatives on the generation of UVA-induced reactive oxygen species in the skin of hairless mice and pharmacokinetic analysis on organ distribution of caffeic acid in ddY mice. Photochem Photobiol 2006, 82:1668-1676.

13. Cheng JT, Liu IM, Tzeng TF, Chen WC, Hayakawa S, Yamamoto T: Release of beta-endorphin by caffeic acid to lower plasma 
glucose in streptozotocin-induced diabetic rats. Horm Metab Res 2003, 35:25I-258.

14. Jung UJ, Lee MK, Park YB, Jeon SM, Choi MS: Antihyperglycemic and antioxidant properties of caffeic acid in $\mathrm{db} / \mathrm{db}$ mice. J Pharmacol Exp Ther 2006, 3 18:476-483.

15. Lowry OH, Rosebrough NJ, Farr AL: Protein determination with the Folin phenol reagent. J Biol Chem I95I, 193:265-275.

16. Biggs HG, Erikson JM, Moorehead WR: A manual colorimetric assay of triglycerides in serum. Clin Chem 1975, 21:437-44I.

17. Rudel LL, Morris MD: Determination of cholesterol using ophthalaldehyde. J Lipid Res 1973, I4:164-166.

18. Jain SK, Palmer M: The effect of oxygen radical metabolites and vitamin E on glycosylation or proteins. Free Rad Biol Med 1997, 22:593-596.

19. Privratsky JR, Wold LE, Sowers JR, Quinn MT, Ren J: AT I blockade prevents glucose-induced cardiac dysfunction in ventricular myocytes: role of the ATI receptor and NADPH oxidase. Hypertension 2003, 42:206-2I2.

20. Yamada T, Sato A, Nishimori T, Mitsuhashi T, Terao A, Sagai $H$, Komatsu M, Aizawa T, Hashizume K: Importance of hypercoagulability over hyperglycemia for vascular complication in type 2 diabetes. Diabetes Res Clin Prac 2000, 49:23-31.

21. Shen L, He X, Dahlback B: Synergistic cofactor function of factor $V$ and protein $S$ to activate protein $C$ in the inactivation of the factor VIIlafactor IXa complex - species specific interactions of components of the protein $\mathbf{C}$ anticoagulant system. Thromb Haemost 1997, 78: 1030-1036.

22. Urano T, Ihara H, Suzuki Y, Takada Y, Takada A: Coagulation-associated enhancement of fibrinolytic activity via a neutralization of PAI-I activity. Semin Thromb Hemost 2000, 26:39-42.

23. Hori M, Nishida K: Oxidative stress and left ventricular remodeling after myocardial infarction. Cardiovasc Res 2009, 8I:457-464.

24. Mohamed-Ali V, Armstrong L, Vlark D, Bolton CH, Pinkney JH: Evidence for the regulation of levels of plasma adhesion molecules by inflammatory cytokines and their soluble receptors in type I diabetes. J Inter Med 200I, 250:4I5-42I.

25. Aso Y, Okumura K, Yoshida N, Tayama K, Kanda T, Kobayashi I, Takemura $Y$, Inukai T: Plasma interleukin-6 is associated with coagulation in poorly controlled patients with Type 2 diabetes. Diabetic Med 2003, 20:930-934.

26. Takahashi K, Mizuarai S, Araki H, Mashiko S, Ishihara A, Kanatani A Itadani $\mathrm{H}$, Kotani $\mathrm{H}$ : Adiposity elevates plasma MCP-I levels leading to the increased CDI I b-positive monocytes in mice. J Biol Chem 2003, 278:46654-46660.

27. Martinovic I, Abegunewardene N, Seul M, Vosseler M, Horstick G Buerke M, Darius H, Lindemann S: Elevated monocyte chemoattractant protein-I serum levels in patients at risk for coronary artery disease. Circulation J 2005, 69: | 484-| 489.

28. Han DH, Lee MJ, Kim JH: Antioxidant and apoptosis-inducing activities of ellagic acid. Anticancer Res 2006, 26:360I-3606.

29. Tasaki M, Umemura T, Maeda M, Ishii Y, Okamura T, Inoue T, Kuroiwa $Y$, Hirose M, Nishikawa A: Safety assessment of ellagic acid, a food additive, in a subchronic toxicity study using F344 rats. Food Chem Toxicol 2008, 46: I I I9-I I 24.
Publish with Bio Med Central and every scientist can read your work free of charge

"BioMed Central will be the most significant development for disseminating the results of biomedical research in our lifetime. "

Sir Paul Nurse, Cancer Research UK

Your research papers will be:

- available free of charge to the entire biomedical community

- peer reviewed and published immediately upon acceptance

- cited in PubMed and archived on PubMed Central

- yours - you keep the copyright
BioMedcentral 